\title{
Plato's Socrates and a new interpretation of the kosmos
}

\section{Z.Zelinová}

Comenius University in Bratislava,

2, Gondova str., Bratislava 1, 811 02, Slovak Republic

For citation: Zelinová Z. Plato's Socrates and a new interpretation of the kosmos. Vestnik of Saint Petersburg University. Philosophy and Conflict Studies, 2021, vol. 37, issue 1, pp. 53-63.

https://doi.org/10.21638/spbu17.2021.105

One of the most common problems encountered in present-day research into ancient natural

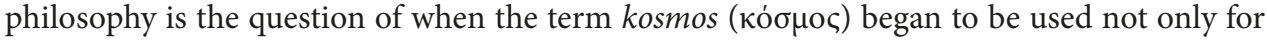
order, but also for the meaning of world order. This article attempts to argue that this new interpretation of kosmos is connected with Socratic thought and asserts that the Socratic anthropological turn can only be meaningfully discussed due to changes in the field of natural philosophy. This anthropological turn is best expressed by Roman orator and philosopher Cicero in his well-known work Tusculan Disputations. The article attempts to offer an interpretation based on the belief that the collocation world order presumes a philosophical turn towards a focus on humans and their internal world experiences. For the author's interpretation, the

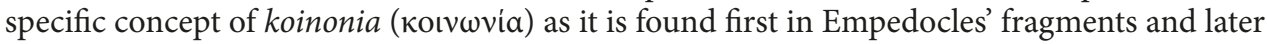
in Plato's philosophy is important. The article consists of three parts: the first part deals with several traditional meanings of kosmos (Homer, Hesiod, Thales, Anaximenes, Anaximander, Heraclitus, Pythagoreans etc.), the second part with meanings that Socratic philosophy (especially Plato, partly Xenophon) assigns to the term, and the final part attempts to argue that it is explicitly Plato who first began using kosmos with the meaning of world or world order.

Keywords: Empedocles, Socrates, Plato, kosmos, cosmology.

One of the best-known quotes that shape our view of the history of Western philosophy is a sentence in Cicero's Tusculan Disputations - "But Socrates was the first who brought down philosophy from the heavens, placed it in cities, introduced it into families, and obliged it to examine into life, morals, and good and evil" (Tusc. disp. V. 10.12-14). This quote perfectly encapsulates the paradigmatic shift that Socrates and Socratic philosophy brought to the field. The common interpretation of it places an emphasis on the anthropological turn, which is a turn away from researching the fysis and one toward humanity, i. e., research into morals, good, and evil. Socrates is simply the first Greek philosopher to focus on humans, their soul, and various aspects of the good life. The following article will diverge from this interpretation to some degree, and it will attempt to postulate and reason for the hypothesis that the Socratic anthropological turn can only be discussed thanks to the turn that took place in the field of natural philosophy, which took

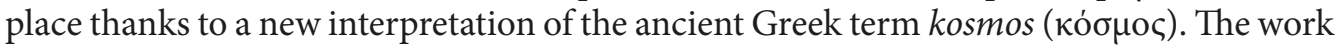
will focus on what may be hidden within the first part of Cicero's quote (Socrates autem

* This article was supported by the Slovak Research and Development Agency under contract no. APVV-18-0103, Paradigmatic Changes in the Understanding of Universe and Man from Philosophical, Theological, and Physical Perspectives.

(C) St. Petersburg State University, 2021 
primus philosophiam devocavit e caelo), with the text being divided into three main parts. The first part discusses some traditional meanings of kosmos, the second part focuses on meanings that Socratic philosophy (especially Plato) assigns to the term, and the final part attempts to argue that Plato is the philosopher who first began using kosmos with the meaning of world as world order.

\section{Kosmos before Socrates}

Despite the fact that Kirk, Raven, and Schofield [1, p.20-99] state that the creators of the first cosmogonies were Homer, the Orphics, and Hesiod, these figures were probably unaware that they were creating cosmogonies or cosmologies [2, p. 27-47], and they were not even familiar with the meaning of kosmos as it is commonly used today as a sort of world order, arrangement, and primarily a concept meaning space and sky. One of the most fundamental questions in the current historiography of ancient Greek philosophy is

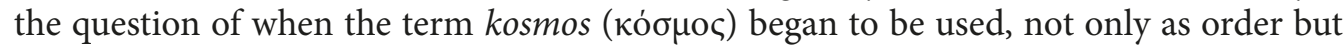
also as world order [3, p. 1]. Even though there is no consensus in academia on what the original meaning of the term was, or what the word stem of kó $\mu$ os is, two main lines of interpretation can be identified. Authors such as Liddell, Scott, Stephano, Thayer, Valpy, and Boisacq suggest that the original meaning of the word was derived from the word order or arrangement. The original meaning in the sense of adornment or decoration is discussed in Curtius, Cremer, French, and Humbolt [4, p. 63], and with this meaning as mundus it was also translated by Roman authors.

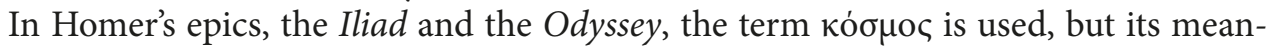

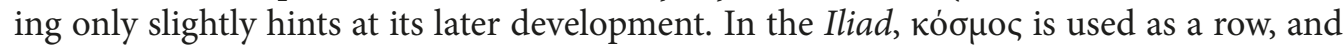
specifically as rows of battle-gear ${ }^{1}$ (Homer, Il. X. 472); in another section it is used to mean order in the sense of social convention ${ }^{2}$ (Homer, Il. II.214) and elsewhere as a sort of decoration or adornment (Il. XIV. $187^{3}$ and IV. $145^{4}$ ). Despite the fact that the initial idea of kó $\sigma \mu \mathrm{o}$ c may focus more on something physically pretty and ordered, rather than something morally or socially correct, the Odyssey shows the word used as an adjective meaning unmannerly or not right: Odysseus refers to Euryalus' speech as unmannerly - "Thou

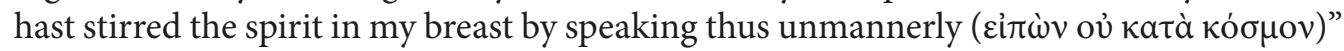

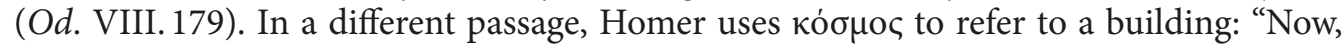

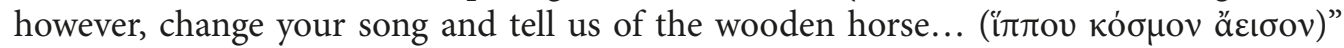
(Od. VIII. 492). It is interesting that in sections where one would intuitively expect the use

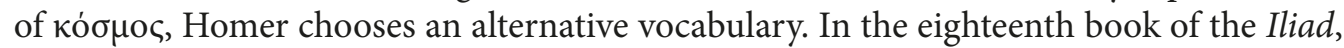
he sings of the creation and arrangement of the whole world which is placed on Achilles's shield (Il. XVIII. 468-617). The fictional creator of the order of the world is Hephaestus, the god of blacksmiths, who creates the entire known world - the territory of humans as one full of polarities and dichotomies: i. e., terra firma, the starry sky, and the ocean [2,

1 "Now these were slumbering, foredone with weariness, and their goodly battle-gear lay by them on the

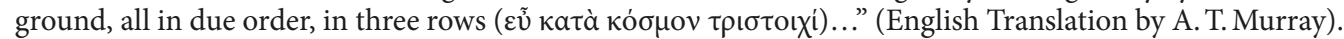

2 "Only there still kept chattering on Thersites of measureless speech, whose mind was full of great

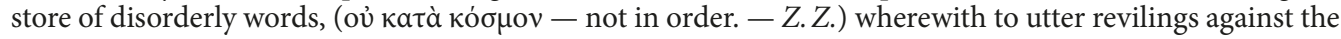
kings..." (Il. II. 212-214).

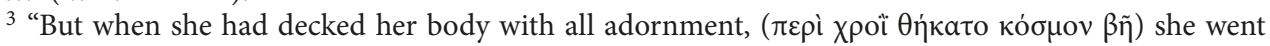
forth from her chamber..."

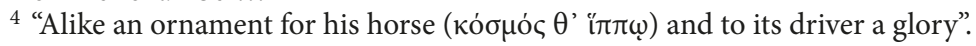


p. 27-47]. Even though the world in this case genuinely only forms a sort of decoration

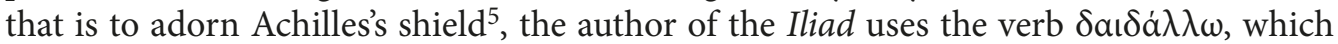
finds its English equivalent in the verbs craft or embellish. When Homer describes the creation of the world, the term kó $\mu \mu \mathrm{o}$ is not yet used.

Some authors [5, p.219] consider Hesiod to be a key figure in the shift from chaos to kosmos in ancient Greek thought: a shift from the lack of order to an ordered world. These types of assessments have their own philosophical rationale, but a philological analysis

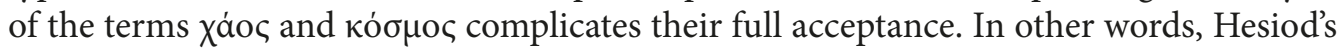
chaos $^{6}$ does not yet mean chaos in the sense we would recognize as a sort of lack of order,

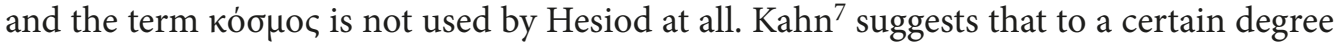

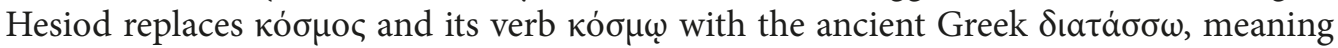
command, order, or appoint (Hesiod, Theog. 74). For the historian Herodotus, the meaning of the word кó $\mu$ os somewhat overlaps ${ }^{8}$ with the Homeric use of the word, with the exception of the metaphorical meaning, which indicates a sort of honour or merit (Herodotus, Hist. VIII. 60 or VIII. 142).

Other researchers [7, p. 204-219] offer the opinion that it is primarily the Greek natural philosophers who dealt with kosmos, i. e., the cosmic riddle, and analysed the origin, structure, and consistency of the universe. Even though some modern researchers ${ }^{9}$ like to use terms such as creators of the first cosmogonies/cosmologies in connection with preSocratic thinkers, it would appear that most of them think of cosmogony as the sum of all knowledge, referencing various problems and questions dealing with fysis, i. e., nature, such as whether all things are created from a combination of four elements or whether they consist of atoms [3, p.xxx]. In connection with the founder of Ionian natural phi-

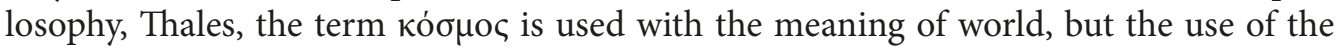
term with this meaning in the Miletus school is highly dubious. This meaning is only brought into connection with Thales's thought in Diogenes Laërtius ${ }^{10}$, who was active around the turn of the second and third centuries CE. There are similar issues with Anaximenes and Anaximander. Even though Anaximander is considered to be the father of

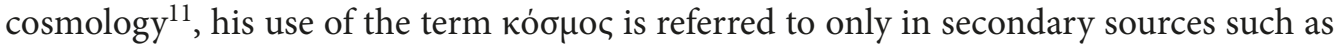

5 This sort of shield decoration was uncommon.

${ }^{6}$ Kirk, Raven, and Schofield are inclined towards Cornford's interpretation of Hesiod's use of $\chi$ áoc, and they claim the substantive derives from the stem $\chi \dot{\alpha}$, which refers to a gap or opening, thus not empty space but rather an interval that is somehow bounded [1, p. 56]. According to this interpretation, Hesiod's "in the beginning of time there was chaos" would mean that between heaven (Oủpavócu) and earth (Гaĩa) there was a gap, and the first stage of cosmogony was the distancing of the sky from the earth.

${ }^{7}$ Kahn offers this hypothesis based on the similarity between Herodotus's statement about the etymol-

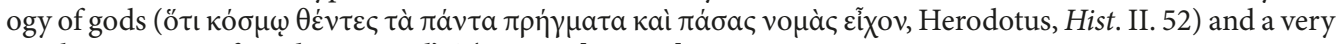
similar statement found in Hesiod's Theogony [6, p. 12].

${ }^{8}$ Herodotus, Hist. II. 52.

${ }^{9}$ Couprie offers Dicks [8] and Furley [9] as examples of such authors [10].

10 "His doctrine was that water is the universal primary substance, and that the world is animate and

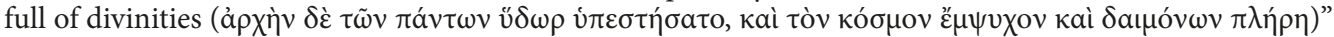
(DL. Vitae, I.27).

${ }^{11}$ Statements are subscribed to Anaximander of Miletus as follows: (1) the movement of celestial bodies does not stop at the horizon; (2) the earth floats in space with no support; and (3) celestial bodies are located at various distances from us $[3, \mathrm{p}$. xxii] . 
Simplicius's In Physica ${ }^{12}$ and Hippolytus ${ }^{13}$. Anaximenes's ${ }^{14}$ use of the term is referred to in Aëtios's De Placita Philosophorum (Vetusta Placita) from the first century CE ${ }^{15}$. Besides the fact that the views of these natural philosophers, with the exception of the peripatet$\mathrm{ics}^{16}$, are referred to through authors ${ }^{17}$ who lived in the first to third centuries CE, the meaning and hence translation of kosmos are unclear. In preserved fragments, this word could also be translated as arrangements or elements. In the same fragments, a sort of equivalent to the world, and primarily to something much closer to what today would be called the universe or space, is presented by the ancient Greek substantive oủpavó (which in some cases is also a proper noun $)^{18}$. In the given context, this begs the question of what the difference between universe and world is. Very intuitively, one could reply that while world is narrower and indicates collocations such as our world and this world with reference to the area or sphere of humans, the term universe is much broader. In pre-Socratic thought, universe could be substituted under the Greek substantive rav (even though English uses the universe for space). While $\pi a v$ indicates everything, so to speak, кó $\sigma \mu \varsigma$ presupposes a sort of structure ${ }^{19}$, or an ex definitio order, world order, or arrangement ${ }^{20}$.

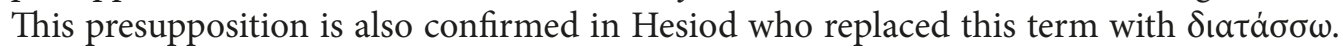
According to Kahn, natural philosophers used the old idea of $\delta a \sigma \mu o ́ \varsigma$ and its original meaning as the division of shares between the gods, and they began to use it as a description for the rational order of the heavens. These philosophers began to talk of a division of natural powers, and to them kosmos began to mean the arrangement of all things, where every natural power has an assigned function and limits [7, p. 12].

12 "It is said that [the beginning] is neither water, nor one of the so-called elements, but rather a different sort of nature, unlimited and from which the heavens and worlds in them are created $(\lambda \varepsilon \dot{\gamma \varepsilon \iota} \delta$ ' aủrìv

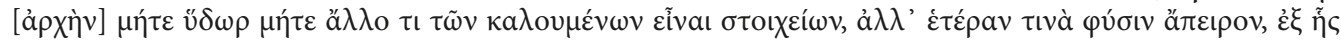

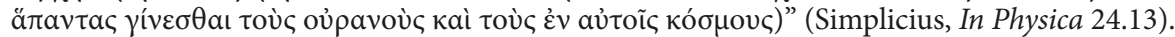

13 "This man said that the originating principle of existing things is a certain constitution of the Infinite, out of which the heavens are generated, and the worlds therein; and that this principle is eternal

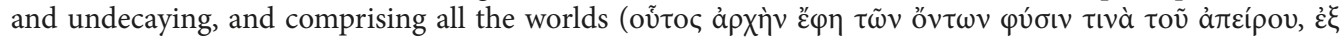

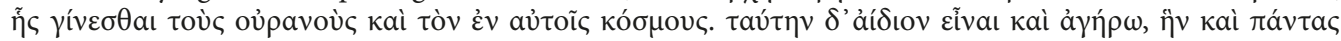

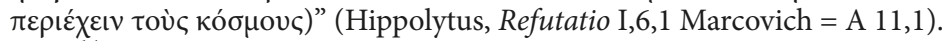
p. 160].

${ }_{14}$ Jaeger suggests that Anaximenes' fragment DK B2 represents the "discovery of the kosmos" [11,

15 "In a similar manner as our soul is air and holds us together, so also the wind and air encompass the

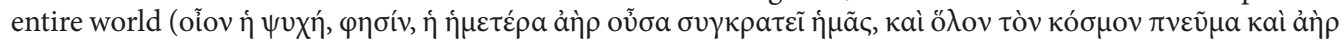

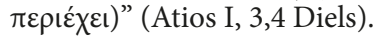

${ }^{16}$ It is known that Aristotle and Theophrastus reinterpreted terms used by pre-Socratic thought and in that way read individual teachings. According to Kahn, the Greek term $\varphi$ v́øıৎ, which in Empedocles refers to the entire process of maturing, i. e., the entire natural development from birth to adulthood, is one century later interpreted by Aristotle as true nature or a form of a fully developed thing [12, p. 75]. Hobza points out Aristotle's dubious interpretation of the pre-Socratic concept of arché [13, p. 889-924].

17 The listed authors of doxographies usually drew from Aristotle's and Theophrastus's work ( $\Delta o ́ \xi \alpha \iota)$, which is lost to time, and Aëtius's Vetusta Placita, which Hermann Diels attempted to reconstruct in the nineteenth century CE.

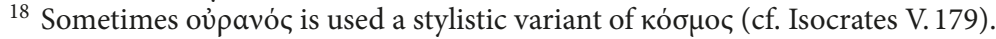

${ }^{19}$ Couprie also assumes an emphasis on the structure in the framework of kosmos, or cosmology: "...cosmology, which deals with the creation of a general picture of the overall structure of space" [10, p. $x x x]$.

${ }^{20}$ According to Kratochvíl, the mythical expression of this arrangement is Orpheus's play, which is heard by all animals, wild or tame, who would otherwise devour one another [14, p. 34]. 


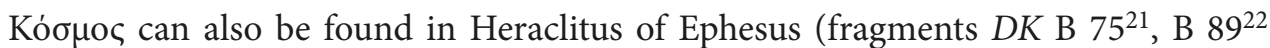
and $\mathrm{B} 30^{23}$ ). However, according to Finkelberg [15, p. 115-116], only fragment B30 can be considered to be authentic, and it should still be read with the Homeric meaning of order. In all listed fragments, kosmos is connected to humans, their inner lives, and their personal experiences. Huffman [16, p. 97-98] takes the view that Heraclitus's use of the word is important and represents a change and shift in meaning from general order to ordered whole, whereas only with Philolaus does the meaning shift to world order. Finkelberg [15, p.129] argues against this position and claims that Philolaus's fragments containing the word kosmos are inauthentic and were only created in the post-Platonic period.

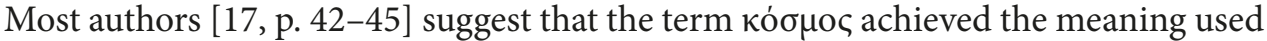
today thanks to the Pythagoreans ${ }^{24}$. Diogenes Laërtius states that Pythagoras was the first

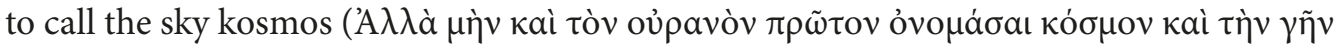
$\sigma \tau \rho o \gamma \gamma v \dot{\lambda} \eta \nu$ ). However, according to Theophrastus, it was Parmenides and according to Zeno, Hesiod, (DL. Vitae, VIII. 48 = Favorinus ${ }^{25}$, fr. 99 Amato). A similar record can be

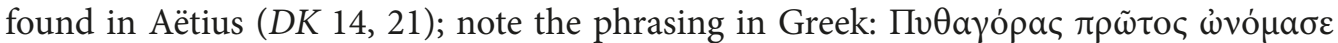

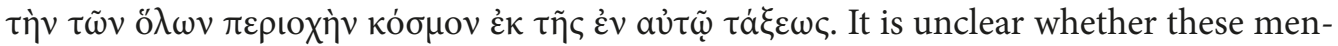
tions are part of a tendency to view Pythagoras as a mythical pioneer in nearly every field. Among other things, Pythagoras was the discoverer of definitions (Aristoteles, Metaph. I. 5.987a13-27), the first to consider physiognomic research (Iamblichus, Vitae Pyth. 71; Porphyry, VP 13), and the first to use the words philosophy and philosopher (DL. Vitae,

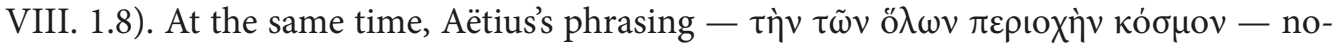

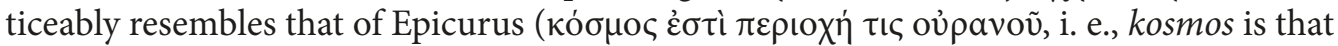
which surrounds the sky, Pyth. 88, cf. 112) and that of some of Aristotle's work (o $\pi \varepsilon \rho\llcorner\varepsilon \dot{\chi} \omega v$

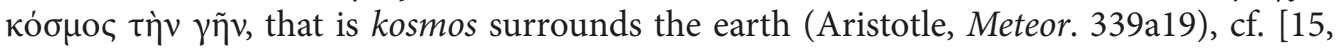
p. 125].

For this reason, it would appear that the given meaning for kosmos (sky) could only be attributed to the final generation of Pythagoreans and generally achieved popularity probably only in the early fourth century CE.

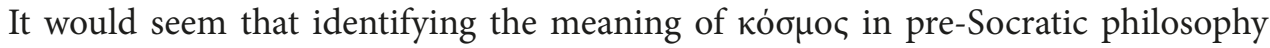
is no mean feat. Hesiod does not use the term at all, and its use by the Milesians is only mentioned in Aristotle, the Peripatetics (who bring their own meanings to pre-Socratic terminology), or in late Hellenistic writers. What appears to be the case is that even when

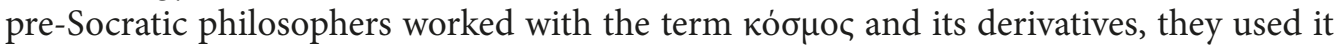
in the earlier Homeric sense to mean order, arrangement, and structure, not necessarily coupled with the modifier world. As stated earlier, world as a modifier indicates a connection to humans, which to some degree is firstly hinted at in Heraclitus's fragments. The authenticity of these fragments is questionable. Despite the fact that Heraclitus is usually considered a critic of Homer (cf. DK 22 B $42=$ DL. Vitae, IX. 1), multiple authors sug-

21 "(Heraclitus also says that) Those who are asleep are fellow-workers in what goes on in the world

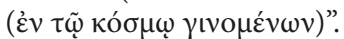

22 "The waking have one common world, but the sleeping turn aside each into a world of his own (Toĩ

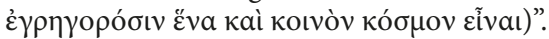

23 "This world, which is the same for all, no one of gods or men has made. But it always was, is, and will

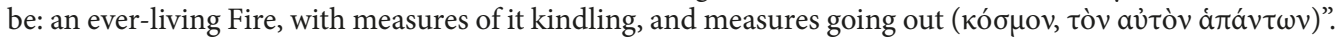

${ }^{24}$ Disagreement with this opinion is voiced by Kahn, for instance, who suggests the statement originates from Favorinus and has nearly no historical relevance [7, p. 9].

${ }^{25}$ Favorinus probably sourced his information from Eratosthenes and Eudemus of Rhodes [5, p. 267]. 
gest ${ }^{26}$ that his thought and style were influenced by the blind poet. At the same time, it can be presupposed that messages about Pythagorean primacy around the new word kosmos are a reaction to theoretical research into fysis being conducted by the latest generation of philosophers pledging allegiance to the Pythagorean school, and that the first thinkers who worked with the new definition were students of Socrates: notably Plato and, to some degree, Xenophon.

\section{Plato, Empedocles, and the kosmos}

Despite the fact that Plato's Timaeus is the most famous ancient philosophical text on the creation of the world and space, Socratic literature contains further mentions of

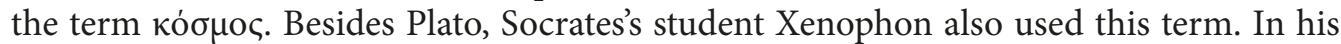
Memorabilia, Xenophon states: "Yet none ever knew him to offend against piety and religion in deed or word. He did not even discuss that topic so favoured by other talkers, 'The Nature of the Universe': and avoided speculation on the so-called "Cosmos" of the Professors, how it works, and on the laws that govern the phenomena of the heavens:

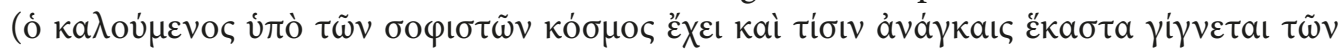
oujpavi $\omega v)$, indeed he would argue that to trouble one's mind with such problems is sheer folly"27 (Mem. I. 1.11-12).

It appears obvious that the primary goal of Xenophon's ideas was to completely distance Socrates from the famous accusation that "Socrates is a criminal and a busybody,

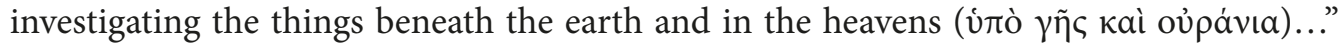
(Plato, Apol.19b). Xenophon's bias is so readily apparent that the main and strongly apologetic meaning of the text need not be discussed herein. Instead, it is important to place an emphasis on how he uses the terms kosmos and uranos. A quote from Xenophon's Memorabilia unequivocally connects kosmos with a meaning referring to world order, and later scholars such as Gigon [19, p. 54] and Dodds [20, p. 308] suggested this meaning was considered fairly novel in Xenophon's times. The translation of kosmos into English as the

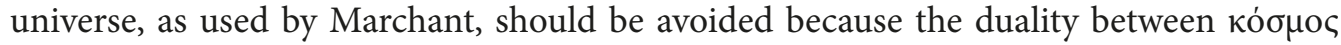
and oủ pavóc likely played an important role in the text where Socrates - in matters of the nature of all things ( $\pi \varepsilon \rho i \tau \tilde{\eta} \varsigma \tau \tilde{\omega} v \pi \dot{\alpha} v \tau \omega \nu ~ \varphi \dot{v} \sigma \varepsilon \omega \varsigma$ ) — was not preoccupied with the physical nature of things on earth or in the sky. This duality could also correspond with the phrasing of the accusation ( $\gamma \tilde{\eta}$ and oúpávio $)$. One of the fundamental problems that the quoted section draws attention to is the question of who, in this case, the oi oopı Finkelberg suggests this is a reference to members of Plato's Academy; her hypothesis is, however, grounded in some dubious premises ${ }^{28}$. On the other hand, Huffman [16, p.318] claims the phrase could refer to certain pre-Socratics: perhaps Anaximenes, Alcmaeon, Diogenes of Apollonia, Philolaus, or Empedocles.

26 Škvrnda and Kalaš, on the other hand, posit that the Homeric provenience of the Heraclitan tradition is also testified to by Plato, who in multiple dialogues states Homer as the originator of the idea of panta rei (Plato, Tht. 152e and Crat. 402a), cf. [18, p. 817].

${ }^{27}$ English Translation by Marchant.

${ }^{28}$ Finkelberg postulates three prerequisites: (a) kosmos meaning world order, or meaning of the world, is only found in Plato's later dialogues such as Timaeus, Statesman, and Philebus; (b) Xenophon's Memorabilia do not significantly predate Timaeus; and (c) in this dialogue, Plato emphasizes the terminological invention of the word kosmos [15]. 
In the next part of the present study, attempts are made to find some common ground

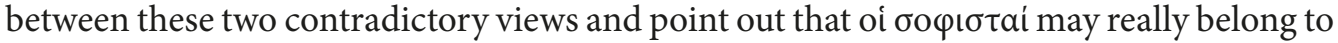
Socrates's student Plato and the interpretation or meaning which he placed onto the word kosmos, which was probably affected by some pre-Socratic teachings. Using Plato as an example, the article will endeavour to show how the Socratic delivery of philosophy from the skies down to earth may have looked.

In connection with the needful man, Plato's Socrates in Gorgias says:

A man who would be blessed with the needful justice and temperance; not letting one's desires go unrestrained and in one's attempts to satisfy them-an interminable trouble-leading the life of a robber. For neither to any of his fellow-men can such a one be dear, nor to God;

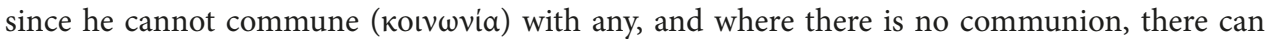

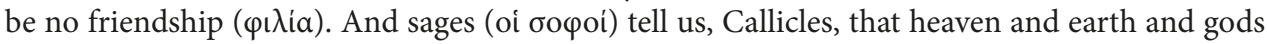
and men are held together by communion and friendship, by orderliness, temperance, and jus-

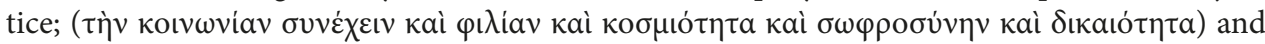
that is the reason, my friend, why they call the whole of this world by the name of order, (кai tò

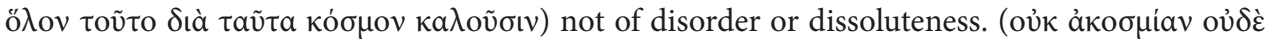

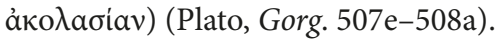

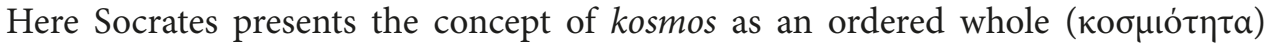
which is interconnected with the world of humans and the realm of the gods. The anthropological turn of Socrates the philosopher shows itself in the change of the interpretation of kosmos moving towards an interconnection with humans. The aforementioned our world or this world point directly to the sphere of that which is human. Plato lists two requirements which are needed for there to be an ordered world to speak of: the com-

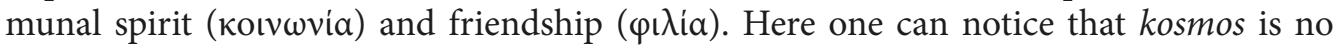
longer connected with the arrangement of some matter or thing, whether it be Homer's tidy arrangement of weapons or the changes and arrangements of pre-Socratic primary matter, but is rather connected with relationship bonds created between one human and another, or between humans and God. Similarly to how Xenophon depicts Socrates, Plato's version also references sages when using the term kosmos; Xenophon speaks of of

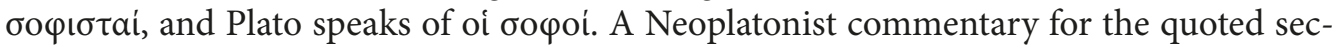
tion of Gorgias, which most researchers ascribe to Proclus [20, p.338-339], survives and states that the term oi oopoi refers to wise Pythagoreans, specifically Empedocles, who claimed that friendship is what connects the spheres and unites everything (schol. ap.

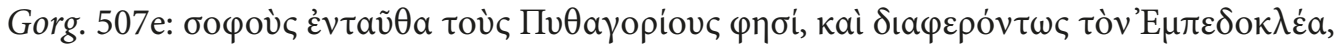

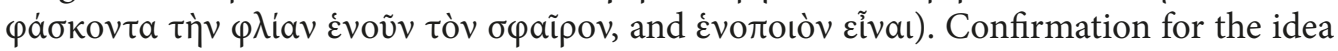
that Plato may be referencing Empedocles can be implicitly found directly in the dialogue.

And we really are, it may be, dead; in fact I once heard sages ( $\tau \tilde{\omega} v \sigma o \varphi \tilde{\omega} v)$ say that we are now dead, and the body is our tomb, and the part of the soul in which we have desires is liable to be

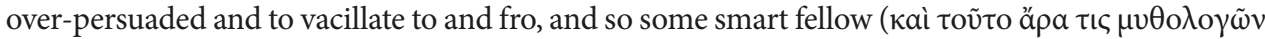

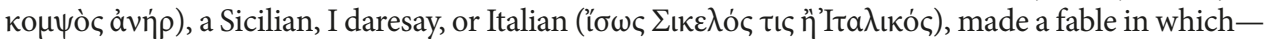
by a play of words-he named this part, as being so impressionable and persuadable, a jar, and the

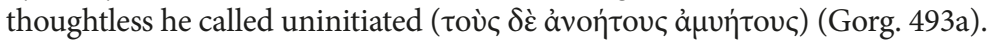

Besides referencing some sages, it also hints at their philosophical identity. Empedo-

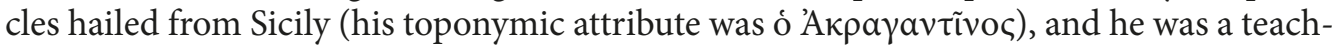
er of Gorgias of Leontini (DL. Vitae, VIII. 2.59). Aristotle connects him with the term 
кобнотога (Phys. II. 4.196a22-23). Originally, he was part of a Pythagorean cult which he was later excommunicated from for making their secrets public (DL. Vitae, VIII. 2.55); his teachings were influenced by the Orphic cult (compare also $\sigma \tilde{\omega} \mu \alpha \dot{\alpha} \varepsilon \tau \tau$ in Gorg. 493a), and he considered himself somehow divine and believed in a reincarnation cycle, i. e., metempsychosis ${ }^{29}$. For this reason, vegetarianism ${ }^{30}$ and asceticism played

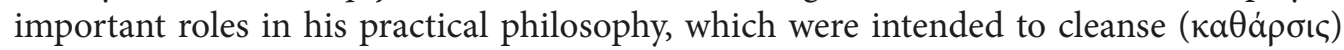
the soul from bodily needs. It seems that in Empedocles there is a sort of necessary connection between philosophical practice (vegetarianism) and the physics of the kosmos. Plutarch's commentary to Empedocles's verses describes a primordial state in which all is unordered and bleak. This state led to a situation where humans began to eat the flesh of animals ${ }^{31}$; the realm of fysis (the lack of order for physical elements) is thus directly interconnected with the lives and actions of humans (humans must eat meat and cannot

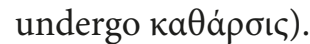

A fragment from Sextus Empiricus more closely explains the connection between éthos and fysis, or koinonia in Gorgias, by claiming that Empedocles's followers believed that koinonia existed between humans and gods as well as between animals lacking minds

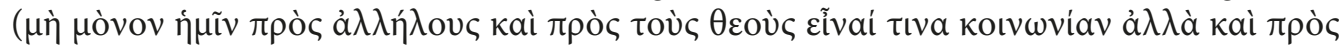

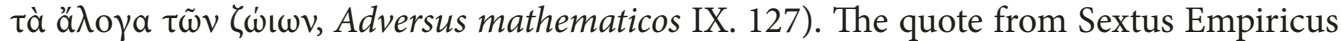
only proves that the interpretation of kosmos as koinonia between god, man, and animal also referred to a practical aspect of philosophy, meaning absolutely no spilling of blood.

The quoted section of Gorgias also contains another element worth pointing out for its importance to Empedocles's kosmogony - filia, i. e., affection and friendship. While in Empedocles love ( $\left.\Phi_{\mathrm{l}} \lambda \mathrm{ó}_{\tau \eta} \varsigma\right)$ is a cosmogonic principle and a cause of movement, which, together with Strife (Neĩkoৎ), controls all elements or gods (DK 31 B 16-17 and DK 31 B 71) and brings them into union, for Plato filia is apparently only a consequence of the aforementioned koinonia. This unity, created with love, represents the kosmos (compare DK 31 B 26: .... Plutarch's description of kosmogony is an important moment, where Empedocles connects with Plato's Timaeus; at the same time, it helps one understand Plato's concept of kosmos as koinonia and as a sort of communality. In his De facie quae in orbe luna apparet (926e),

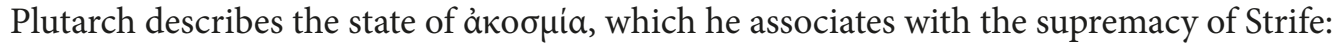

"Earth had no part in heat, water no part in air; there was not anything heavy above or anything light below; but the principles of all things were untampered and unamiable

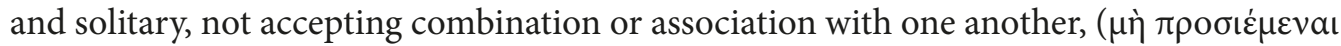

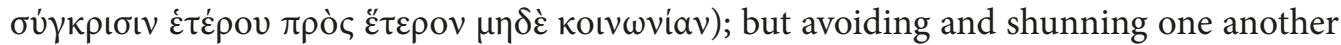
and moving with their own peculiar and arbitrary motions they were in the state which, according to Plato, everything is from which God is absent, that is to say in which bodies are when mind or soul is wanting".

In Timaeus, Plato also describes the state of akosmia: a state where everything was

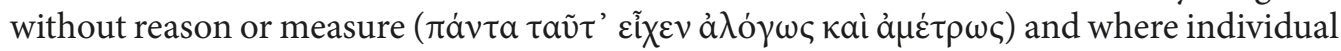
elements moved separately flew in separate directions. This state lasted until God ( $\theta \varepsilon$ ć)

${ }^{29}$ Compare fragment DK B 117: "For I have been ere now a boy and a girl, a bush and a bird and a dumb fish in the sea".

${ }^{30}$ Cf. DL. Vitae, VIII. 2.53, which claims Empedocles sacrificed a steer made of honey and flour to the audience. Here we can see he evidently eschewed blood sacrifice.

${ }^{31}$ For more, compare Plutarch, De esu carn. 993d-ad B 154. 
began working on creation, and the arrangement of elements resulted in space (ö $\tau \varepsilon \delta^{\prime}$

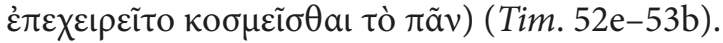

Some researchers ${ }^{32}$ suggest that Plato criticized Empedocles's projection of metaphysical entities onto the human relational network (e. g., friendship, battle, procreation, and birth). This opinion, however, cannot be entirely agreed with because in several places Empedocles considers Love and Strife to be daimons (cf. DK 31 B 16-17 and DK 31 B 71), i. e., as divine beings, similar to how in Plato's Symposion Eros (desire) is considered to be a sort of daimon (Plato, Symp. 202d-e) as well as one of the basic principles of Platonic dialectics. However, part of this criticism can be accepted in modified form, in that Plato does not project the stated terms based on interpersonal relationships onto metaphysical principles pertinent to the creation and order of the world. Nevertheless, there are some analogies between Empedocles and Plato in their cosmological views. The claim that the divine and superhuman mind darts through the whole kosmos with its swift thoughts ( $D K$

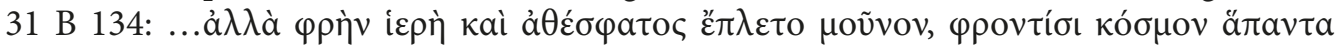

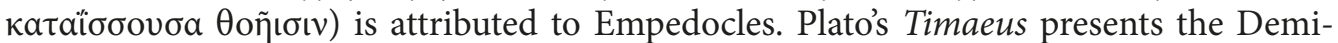
urge, who creates the world with his mind and places in it soul and reason: "...building

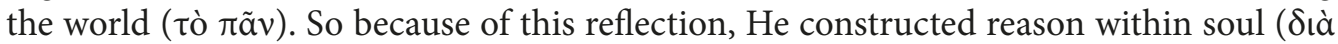

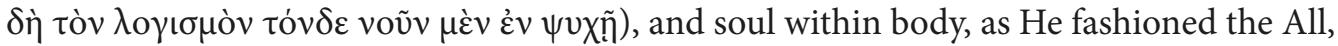
that so the work He was executing might be of its nature most fair and most good. Thus, then, in accordance with the likely account, we must declare that this Cosmos ( $\tau$ óv $\delta \varepsilon$

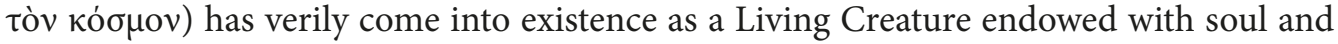

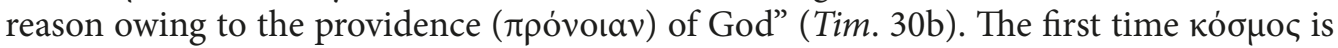
used in the dialogue ${ }^{33}$, its meaning implicitly references the Platonic-Socratic concept of koinonia; in section 24c, Solon listens to a story about a goddess who wrote laws about various aspects of human relationships where kosmos references the whole arrangement based on reasonable laws. Even though in that part the term koinonia is not found directly, it can be assumed that the socio-political context of this section precisely accentuates the idea of social reciprocity, i. e., a well-ordered and just polis. The influence of Empedocles's philosophy in Plato's dialogue is also emphasized in a section which introduces some rules regarding ritual cleansing related to the reincarnation cycle (Tim. 42b-e).

Based on the evidence presented, Xenophon in Memorabilia views the creator of the new meaning for the old term kosmos to be explicitly Plato and his school; however, with oi ooyoi, Plato himself most probably refers to Empedocles. The Empedocleian inspiration in matters of natural philosophy presents a unique starting point for Socratic philosophy and the Socratic anthropological turn as captured in Plato; Empedocles's view of the kosmos seamlessly develops into philosophical views on the world of humans, morals, and a good life. The change in interpretation of the ancient Greek кó $\mu$ os, i. e., the shift from arrangement towards world order, could have only arrived alongside the bringing of philosophy down from heaven to earth, i. e., focusing on humans and their inner lives. Therefore, through Socrates's student Plato, kosmos attains a new meaning and accentuates a sort of meaning of human life. Humans and their lives in the polis form a mikrokosmos, which is, however, firmly interconnected with the surrounding world and space; the in-

${ }^{32}$ For example, Vítek argues for this statement with a reference to the dialogue Sophist (Soph. 242c-e) [22, p. 139].

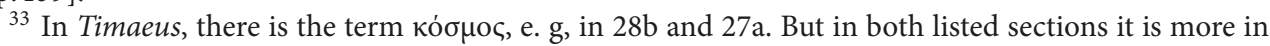
the meaning of "space". 
dividual finds the meaning of life in koinonia, whether that means in relationship to one another or in relationship to the gods.

\section{Conclusions}

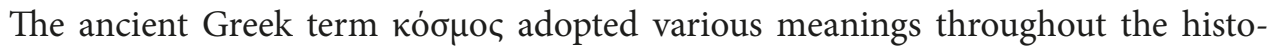
ries of Greek literature and philosophy: from order and decoration in Homeric epics and structure and well-arrangement in the pre-Socratics, through to the later expressions of universe or world in post-Hellenistic authors [21, p.40]. One of the basic problems that is problematic for present-day researchers is the question of when kosmos assumes the meaning of world order. In the present contribution, the attempt has been made to offer an interpretation based on the belief that the collocation world order presumes a philosophical turn towards a focus on humans and their internal world experiences. For this reason, this study concentrated on Socrates and Socratic philosophy, which is usually mentioned in connection with the famous anthropological turn. Based on Plato's Gorgias, there was an endeavour to explain the connection between the new interpretation of kosmos and the concepts of koinonia and filia, which are usually mentioned in connection with Empedocles. At the same time, there is the claim that Empedocles's philosophy may have been a source of inspiration for Plato when connecting the ideas of mikrokosmos and makrokosmos, which he later fully expanded on in Timaeus.

\section{References}

1. Kirk, G. S., Raven, J.E. and Schofield, M. (2004), Předsókratovští filosofové. Kritické dějiny s vybranými texty, Prague: Oikoymenh.

2. Schadewaldt, W. (1991), Homérova básnická ontologie, in Rezek, P. (ed.), Mýtus, epos a logos, Prague: Oikoymenh, pp. 27-47.

3. Gregory, A. (2011), Ancient Greek Cosmogony, Bristol: Bristol Classical Press.

4. Redding, J. (1949), Kosmos from Homer to St. John, The Asbury Seminarian, vol. 4, no. 2, pp. 63-65.

5. Zhmud, L. (2012), Pythagoras and the Early Pythagoreans, Oxford: Oxford University Press.

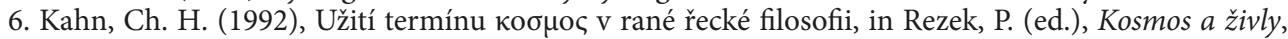
Prague: Oikoymenh, pp. 9-20.

7. Theodossiou, E. and Manimanis, V.N. (2010), The Cosmology of the pre-Socratic Greek Philosophers, Memorie della Societa Astronomica Italiana Supplement, vol. 15, pp. 204-209.

8. Dicks, D. R. (1970), Early Greek Astronomy, New York: Cornell University Press.

9. Furley, D. (1987), The Greek Cosmologist, vol. I: The Formation of the Atomic Theory and its Earlier Critics, Cambridge: Cambridge University Press.

10. Couprie, D. L. (2011), Heaven and Earth in Ancient Greek Cosmology. From Thales to Heraclides Ponticus, London: Springer Science + Business Media.

11. Jaeger, W. (1946), Paideia: The Ideals of Greek Culture, vol. I, transl. by Highet, G., Oxford: Oxford, Blackwell.

12. Kahn, Ch.H. (1960), Anaximander and the Origins of Greek Cosmology, Cambridge: Hackett Publishing Company.

13. Hobza, P. (2004), Aristotelés a Theofrastos jako tvůrci mílétské filosofie, Filosofický časopis, no. 6, pp. 889-924.

14. Kratochvíl, Z. (2003), Filosofie živé prírody, Prague: H\&H.

15. Finkelberg, A. (1998), On the History of the Greek кобнос, Harvard Sudies in Classical Philology, vol. 98, pp. 103-136.

16. Huffman, C. A. (1993), Philolaus of Croton: Pythagorean and Presocratic: A commentary on the Fragments and Testimonia with Interpretative Essays, Cambridge: Cambridge University Press.

17. Mansfeld, J. (1971), The Pseudo-Hippocratic Tract Peri Hebdomadoon: Ch 1-11 and Greek Philosophy (Philosophical Texts \& Studies), Amsterdam: Van Gorcum. 
18. Škvrnda, F. and Kalaš, A. (2014), Homer a predsókratovské myslenie, Filozofia, vol. 69, no. 10, pp. 813-823.

19. Gigon, O. A. (1935), Untersuchungen zu Heraklit, Leipzig: Dieterich'sche Verlagsbuchhandlung.

20. Dodds, E. R. (1959), Plato: Gorgias, Oxford: Clarendon Press.

21. Horky, P. S. (2019), When did Kosmos Become the Kosmos, in Horky, P.S. (ed.), Cosmos in the Ancient World, Cambridge: Cambridge University Press, pp. 22-41.

22. Vítek, T. (2001), Empedoklés, Studie, Prague: Hermann \& Synové.

Received: April 26, 2020

Accepted: December 29, 2020

Author's information:

Zuzana Zelinová - PhD in Philosophy; zelinova9@uniba.sk

\section{Платоновский Сократ и новая интерпретация космоса ${ }^{\star}$}

\section{З.Зелинова}

Университет имени Коменского в Братиславе,

Словацкая Республика, 811 02, Братислава 1, ул. Гондова, 2

Для цитирования: Zelinová Z. Plato’s Socrates and a new interpretation of the kosmos // Вестник Санкт-Петербургского университета. Философия и конфликтология. 2021. Т. 37. Вып. 1. С. 5363. https://doi.org/10.21638/spbu17.2021.105

Один из наиболее актуальных вопросов современных исследований античной натурфилософии - вопрос о том, когда и почему термин космос (греч. ко́бнос) начал использоваться не только в значении порядок, но и в значении мировой порядок. В статье предпринята попытка аргументировать утверждение о том, что новая интерпретация термина космос связана с сократовской философией и что можно говорить о сократовском антропологическом повороте, который произошел вследствие принципиальных изменений в области натурфилософии. Суть антропологического поворота лучше всего была выражена римским оратором и философом Цицероном в его известной работе Тускуланские беседы. Предложенная в статье интерпретация основана на предположении, что придание термину космос значения мировой порядок было обусловлено смещением философского внимания на человека, его внутренний мир и опыт. Такой вывод позволяет сделать анализ концепции koinonie (коเvwvia), которая обнаруживается сначала во фрагментах Эмпедокла, а затем в философии Платона. Статья состоит из трех частей. В первой части рассматриваются некоторые традиционные значения термина космос (у Гомера, Гесиода Фалеса, Анаксимена, Анаксимандра, Гераклита, Пифагора и т.д.), во второй части исследуется использование термина «космос» в сократовской философии (особенно у Платона, частично у Ксенофонта), в третьей части приводятся доводы в пользу утверждения, что Платон является философом, который впервые начал использовать термин космос в значении мир и мировой порядок.

Ключевые слова: Эмпедокл, Сократ, Платон, космос, космология.

Статья поступила в редакцию 26 апреля 2020 г.; рекомендована в печать 29 декабря 2020 г.

Контактная информация:

Зелинова Зузана - канд. филос. наук; zelinova9@uniba.sk

* Публикация поддержана Словацким агентством исследований и разработок в рамках контракта № APVV-18-0103 «Парадигматические изменения в понимании Вселенной и человека с философской, теологической и физической точек зрения». 